\title{
New Records of Two Hydroids(Cnidaria: Hydrozoa) from Korean Waters
}

\author{
Jung Hee Park* \\ Department of Life Science, College of Natural Sciences, The University of Suwon, Hwaseong 445-743, Korea
}

\begin{abstract}
Hydroid specimens were collected from the coasts of Isl. Jeongjokdo (Taean) and Gampo Harbour, Korea, on 10 May and 19 October 2010. Two of the species identified as Sertularia tenera G.O. Sars 1874 and Plumularia halecioides Alder 1859 are new to Korean fauna. They are described with illustrations.
\end{abstract}

Keywords: taxonomy, new record, hydroids, Hydrozoa, Korea

\section{INTRODUCTION}

The sertularian and plumularian hydroids are the largest taxa of the hydroid fauna found in the world's oceans. Currently, 49 sertulariid (32\%) and 36 plumulariid (24\%) species have been recorded in Korean waters by the author and others. These species have no medusa stage, and their planula larvae are delivered from mature polyps for dispersal. The diverse structures of gonothecae, which protect gonophores, develop from their polyps (Brusca and Brusca, 2003).

Materials were collected from the coasts of Isl. Jeongjokdo (Taean) and Gampo Harbour, Korea, by Mr. B.S. Min on 10 May and 19 October 2010, and were deposited at the Department of Life Science of the University of Suwon, Hwaseong, Korea. Permanent specimens were prepared for light microscopy examination. Photographs of individual specimens and colonies were taken using a microscope (E-80i; Nikon, Tokyo, Japan) and a digital camera (EOS 300D; Canon, Tokyo, Japan).

\section{SYSTEMATIC ACCOUNTS}

Phylum Cnidaria Hatschek, 1888

Class Hydrozoa Huxley, 1856

Order Thecatae Fleming, 1828

Family Sertulariidae Hincks, 1868

${ }^{1 *}$ Sertularia tenera G.O. Sars, 1874 (Fig. 1A-G) Sertularia tenera G.O. Sars 1874: 108, Pl. 4, figs. 1-4; Mar-

(c) This is an Open Access article distributed under the terms of the Creative Commons Attribution Non-Commercial License (http://creativecommons.org/ licenses/by-nc/3.0/) which permits unrestricted non-commercial use, distribution, and reproduction in any medium, provided the original work is properly cited.
ktanner-Turneretscher, 1895: 418, Pl. 11, fig. 14; Pl. 12, fig. 5; Pl. 13, figs. 3, 4; Jäderholm, 1919: 15, Pl. 6, fig. 1; Naumov, 1960: 353, fig. 244; Calder, 1970: 1536, Pl. 18, fig. 1; Cornelius, 1979: 299, fig. 27; 1995: 91, fig. 22.

Thuiaria tenera: Ritchie, 1911: 218, figs. 2-5; Fraser, 1921: 42, fig. 100.

Material examined. Korea: Chungcheongnam-do, Taeangun, Isl. Jeongjokdo, 28 May 2010, Min BS, attached on rock in coast.

Description. Colonies erect, pinnate, up to about $50 \mathrm{~mm}$ long. Two types of colonies present: one straight, without hydrothecae on stem; others sinuous with hydrothecae on stem. In some other types of colonies, lower portion of stem without hydrothecae and straight and upper portion of stem with hydrothecae sinuous. Some of branches redivided into dichotomously. Hydrothecae arranged in subopposite or in alternate, tubular, tapering distally, widest in center, abcauline wall slightly concave, with two round marginal teeth equal or outer longer, operculum with two flaps. Gonothecae not observed.

Remarks. Arrangement and inclinations of hydrothecae are variable. In the lower portion of the branches, hydrothecae show an alternate arrangement; however, in the upper portion, hydrothecae show a subopposite arrangement. Hydrothecae incline outward at a $30-60^{\circ}$ angle, and the adcauline wall is adnated about one-third to one-half on the lower portion, with the remainder freely protruding outward.

Distribution. Korea, Japan, North Pacific, North Atlantic, and Arctic Oceans.

\section{*To whom correspondence should be addressed \\ Tel: 82-31-220-2480, Fax: 82-31-220-2480}

E-mail: jhpark5@suwon.ac.kr

Korean name: ${ }^{1 *}$ 고운화관히드라 (신칭) 

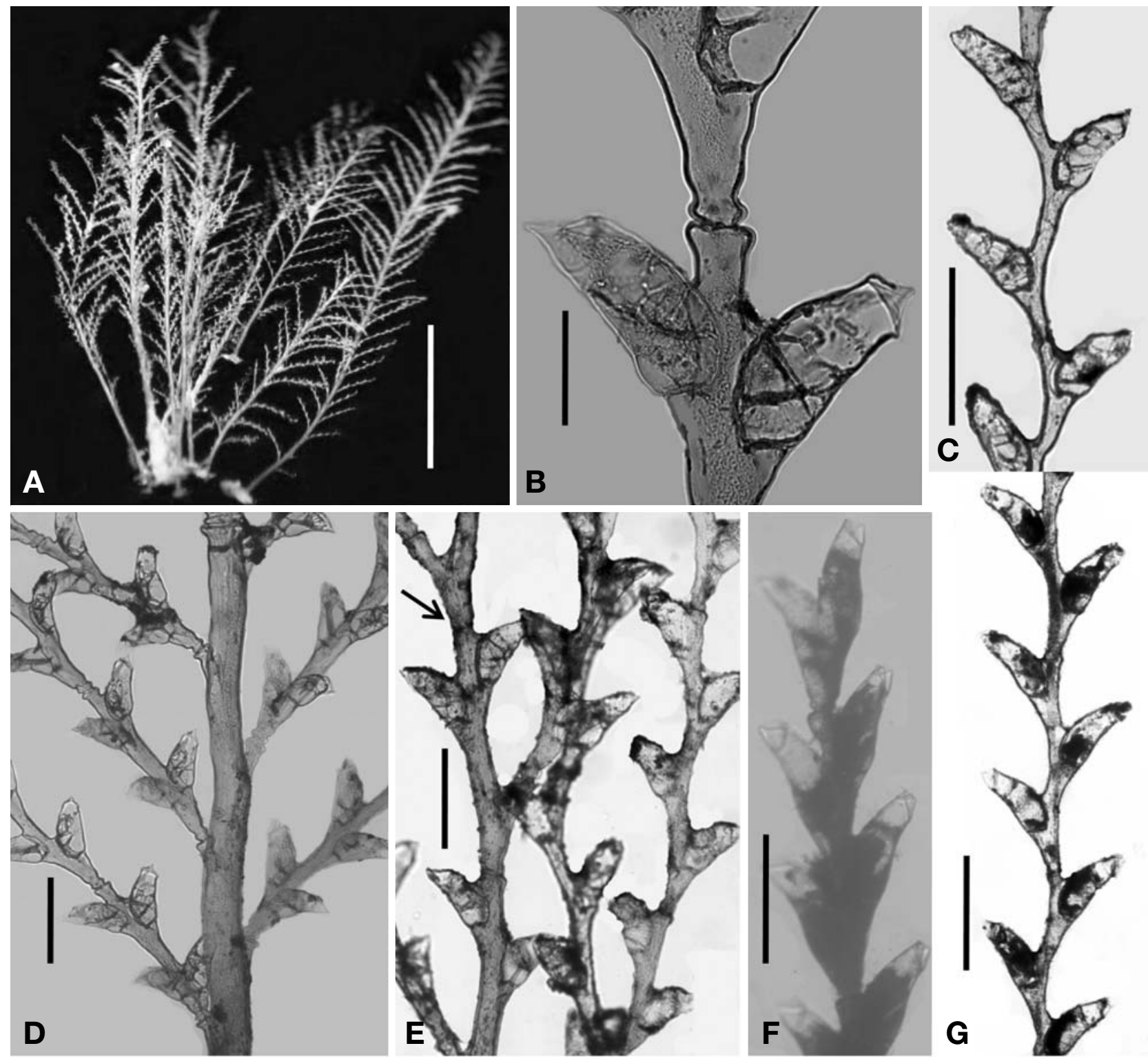

Fig. 1. Sertularia tenera. A, Colonies detached on rock; B, Subopposite hydrothecae; C, E-G, Arrangement of hydrothecae on a monosiphonic stem $(\rightarrow)$ and hydrocladia; $D$, Single internode of stem with six hydrocladia. Scale bars: $A=5 \mathrm{~mm}, \mathrm{~B}=200 \mu \mathrm{m}, \mathrm{C}-\mathrm{G}=500 \mu \mathrm{m}$.

Family Plumulariidae L. Agassiz, 1862

1*Plumularia halecioides Alder, 1859 (Fig. 2A-E)

Plumularia halecioides Alder, 1859: 353, Pl. 12, figs. 1-5;

Hincks, 1868: 306, Pl. 67, fig. 2.

Ventromma halecioides: Stechow, 1923: 220; Hirohito, 1974: 45, fig. 20a-d.

Material examined. Korea: Gyeongsangbuk-do, Gampo Harbor, 19 Oct 2010, Min BS, attached on the shell of biva- lves (Mytilus sp.).

Description. Colonies small, less than $30 \mathrm{~mm}$ high, branched irregularly. Stem polysiphonic throughout, but gradually becomes monosiphonic upward. Branches monosiphonic or polysiphonic and divided into regular internodes; each internode has one hydrocladium arranged in alternate. Hydrocladia arise from stem and branch, which arranged in opposite or in alternate. Hydrocladia divided into thecate internodes with hydrotheca and athecate internodes without hydrotheca. Thecate internode long, with one hydrotheca at one-third its

Korean name: ${ }^{1 *}$ 무늬깃히드라 (신칭) 

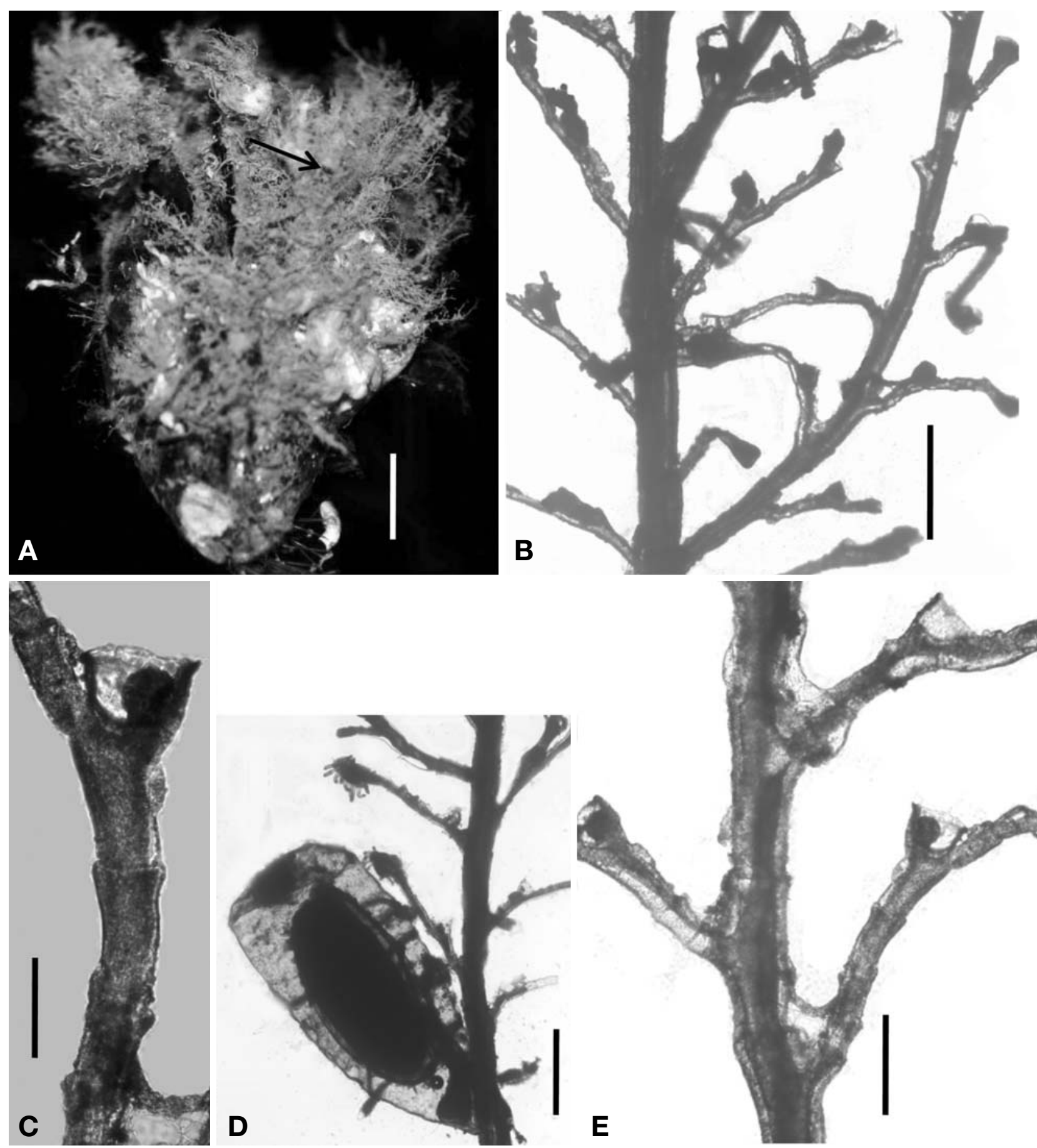

$\mathbf{E}$

Fig. 2. Plumularia halecioides. A, Colonies $(\rightarrow)$ on the shell surface of Mytilus sp.; B, Polysiphonic stem and branches with hydrocladia; C, Hydrothecal internode with a hydrotheca and nematothecae; D, Gonotheca on the basal portion of the stem; E, Monosiphonic stem with hydrocladia. Scale bars: $A=10 \mathrm{~mm}, \mathrm{~B}, \mathrm{D}=500 \mu \mathrm{m}, \mathrm{C}=100 \mu \mathrm{m}, \mathrm{E}=200 \mu \mathrm{m}$.

upper side, one inferior nematotheca, one upper mesial nematotheca. Hydrotheca shallow, present on upper side, and directed obliquely upward; adcauline wall largely adhering and has a short free part. Nematotheca nonthalamical and im- movable. Gonotheca large compared with hydrotheca, arise from basal portion of stem or stolon, cylindrical, and taper gradually below with many transverse rings over almost its surface; pedicel short, slender and located above truncate 
with orifice.

Remarks. This species is similar to Plumularia inermis (see Fraser, 1944) in terms of the shape and position of the hydrotheca, nematotheca, and gonotheca; however, it also differs from the latter, having a monosiphonic and unbranched stem.

Distribution. Korea, Japan, Britain, and Venezuela.

\section{ACKNOWLEDGEMENTS}

This work was supported in part by the Invasive Species Management Program in Marine Ecosystem (2010), Korean Ministry of Land, Transport and Maritime Affairs of Korean Government.

\section{REFERENCES}

Alder J, 1859. Description of three new species of sertularian zoophytes. Annals and Magazine of Natural History, 3:353355.

Brusca RC, Brusca GJ, 2003. Invertebrates. 2nd ed. Sinauer Associates, Sunderland, MA, pp. 219-261.

Calder DR, 1970. Thecate hydroids from the shelf waters of northern Canada. Journal of the Fisheries Research Board of Canada, 27:1501-1547.

Cornelius PFS, 1979. A revision of the species of Sertulariidae (Coelenterata: Hydroida) recorded from Britain and nearby seas. Bulletin of the British Museum Natural History Zoology, 34:243-321.

Fraser CM, 1921. Hydroids. Key to the hydroids of eastern
Canada. Contributions to Canadian Biology and Fisheries, 17:137-180.

Fraser CM, 1944. Hydroids of Atlantic coast of North America. University of Toronto Press, Toronto, pp. 1-457.

Hincks T, 1868. A history of the British hydroid zoophytes. Van Voorst, London, Vol. 1. pp. 1-338; Vol. 2, pp. 1-227.

Hirohito, 1974. Some hydrozoans of the Bonin Islands. Publications of the Biological Laboratory, Imperial Household, Tokyo, 11:1-55.

Jäderholm E, 1919. Zur Kenntnis der hydroiden fauna Japan. Arkiv für Zoologi, 12:1-34.

Marktanner-Turneretscher G, 1895. Zoologische Ergebnisse der im Jahre. 1889 auf Kosten der Bremer Geographischen Gesallschaft von Dr. Willy Kükenthal und Alfred Walter ausgeführten Expedition nach Ost-Spitzbergen. Hydroiden Zoologische Jahrbücher, Abteilung für Systematik, 8:391438.

Naumov DV, 1960. Hydroids and hydromedusae of the USSR. Opred Faune SSSR 70:1-660.

Ritchie J, 1911. Contribution to our knowledge of the hydroid fauna of the West of Scotland. The Annals of Scottish Natural History, 20:217-225.

Sars GO, 1874. Bidrag til kundskaben om Norges hydroider. Forhandlinger i Videnskabs Selskabet i Christiania, 1873: 91-150.

Stechow E, 1923. Zur Kenntrnis der Hydroidenfauna des Mittelmeeres, Amerikas und anderer Gebiete. Zoologische Jahrbücher, Abteilung für Systematik, 47:29-270.

Received January 21, 2011 Accepted March 3, 2011 